\title{
ANALISIS PENGARUH KUALITAS SISTEM MEDIA ELEKTRONIK e-Filing DAN e-Billing TERHADAP TINGKAT KEPUASAN WAJIB PAJAK (Studi Pada Wajib Pajak di Fakultas Ekonomi Universitas Tridinanti Palembang)
}

\author{
Dimas Pratama Putra ${ }^{1}$, Padriyansyah ${ }^{2}$ \\ 1,2Fakultas Ekonomi, Universitas Tridinanti \\ dimaspratamaputra@univ_tridinanti.ac.id
}

Diterima 28 April 2019, Disetujui 03 Mei 2019

\begin{abstract}
Abstrak
Penelitian ini dilakukan terhadap pembayar pajak di fakultas ekonomi Tridinanti Palembang. Penelitian ini bertujuan untuk mengetahui pengaruh kualitas sistem e-filing dan e-billing terhadap tingkat kepuasan wajib pajak. Populasi dalam penelitian ini adalah 339 wajib pajak. Sampel sebanyak 130 wajib pajak dengan menggunakan metode purposive sampling. Teknik analisis yang digunakan adalah analisis deskriptif dan dilakukan uji asumsi klasik. Hasil dari penelitian ini adalah (1). Kualitas sistem e-filing memiliki efek positif yang signifikan terhadap tingkat kepuasan wajib pajak, (2). Kualitas sistem e-filing memiliki pengaruh negatif yang signifikan terhadap tingkat kepuasan wajib pajak, dan (3). Kualitas sistem e-filing dan e-billing secara kolektif memiliki efek positif yang signifikan terhadap tingkat kepuasan wajib pajak.
\end{abstract}

Kata kunci : sistem mutu, e-filing, e-billing dan, tingkat kepuasan wajib pajak

Abstract

This research is being done to taxpayers at economic faculty of Tridinanti Palembang. This research aims to know effect the quality of the e-filing and e-billing system toward taxpayers satisfaction level. The population in this study is 339 taxpayers. Sample of 130 taxpayers by using purposive sampling methods. The analytical technique used is a descriptive analysis and conducted a asumsi klasik test. The result of this study is (1). The quality of the e-filing system has a significant positive effect on the degree of taxpayers satisfaction, (2). The quality of the e-filing system has a significant negative effect on the degree of taxpayers satisfaction, dan (3). The quality of e-filing and e-billing system collectively has a significant positive effect on the rate of taxpayers satisfaction.

Keywords: quality system, e-filing, e-billing and, taxpayers satisfaction level 


\section{PENDAHULUAN}

Pajak merupakan suatu hal yang penting sebagai penerimaan di dalam suatu negara yang merupakan suatu kewajiban bagi setiap warga yang mendapatkan penghasilan atas kegiatan yang dilakukannya untuk melaporkan, menyetorkan terhutang pajak tepat pada waktunya karena pajak yang di setorkan kepada pemerintah oleh wajib pajak akan digunakan untuk kepentingan negara. Besarnya kontribusi pajak di dalam Anggaran Pendapatan dan Belanja (APBN) pun selalu meningkat setiap tahun. Dalam APBN 2017, pemerintah menargetkan pendapatan negara sebesar Rp 1.472,7 Triliun. Dari angka tersebut, sebesar $85,7 \%$ atau $1.339,8$ Triliun sebagian besar pendapatan negara bersumber dari sektor pajak.

Menteri Keuangan sri Mulyani menyebutkan, realisasi penerimaan pajak tahun 2017 mencapai 1.339,8 atau 91,0\% dari target yang ditentukan 1.472,7 Triliun. Dilihat dari target dan realisasi 2017 merupakan pencapaian yang terbaik dari tahun sebelumnya namun tetap target yang telah ditetapkan tidak tercapai. Menyongsong Tahun 2018, Kementerian Keuangan dalam Anggaran Pendapatan dan Belanja (APBN) 2018 mengemban amanah target penerimaan pajak sebesar Rp1.618,1 Triliun. Angka ini melejit 9,9\% dibandingkan tahun 2017 yang terpatok sebesar Rp1.472,7 Triliun. Direktorat Jenderal Pajak harus bekerja ekstra dalam mengejar tambahan Rp144,1 Triliun dari target penerimaan pajak pada tahun 2017. Terlebih pada tahun 2017, realisasi penerimaan pajak baru tercapai 91\%. Dengan demikian, dibutuhkan usaha yang lebih keras lagi dari DJP.

Pajak sifatnya dinamika yang mengikuti perkembangan sosial, ekonomi dan serta masyarakatnya. Tuntutan akan peningkatan penerimaan, perbaikan dan perubahan mendasar dalam segala aspek perpajakan menjadi alasan dilakukannya reformasi pelayanan perpajakan untuk penyempurnaan terhadap kebijakan dan sistem administrasi perpajakan agar basis pajak dapat semakin diperluas, sehingga potensi penerimaan pajak yang tersedia dapat diperoleh secara optimal dengan ketentuan peraturan yang berlaku dan memberikan pelayanan prima kepada wajib pajak.

Peningkatan kualitas pelayanan melalui teknologi informasi berbasis penggunaan komputer maupun smartphone telah menjadi terobosan utama yang dilakukan Direktorat Jenderal Pajak. Sistem Informasi Pajak (SIP) yang berdasarkan pendekatan fungsi telah beralih ke Sistem Administrasi Perpajakan Terpadu (SAPT) ini bersifat desentralisasi artinya di setiap kantor layanan pajak yang dimulai tahun 1994 dan terus diperbaharui hingga adanya sistem elektronik. Sistem Elektronik yang diharapkan dapat memberikan kualitas pelayanan yang mudah, cepat dan efisien.

Dalam fenomena yang terjadi di dalam masyarakat luas khususnya wajib pajak menganggap bahwa sistem administrasi perpajakan dari proses menghitung, melaporkan dan melakukan pembayaran yang tidak mudah belum lagi dalam proses pelaporan dan penyetoran yang banyak menghabiskan waktu, mereka mengharapkan untuk mendapatkan kemudahan dalam sistem pelayanan perpajakan terutama dalam pelaporan dan penyetoran yang tidak perlu lagi memakan waktu yang banyak. Oleh karena itu dalam upaya meningkatkan pelayanan kepada wajib pajak, pemerintah dalam hal ini Direktorat Jendral Pajak terus berusaha memperbaiki sistem pelayanan perpajakan untuk mempermudah dan mengefisienkan pekerjaan yang berhubungan dengan administrasi dan pembayaran pajak. Maka dari itulah Direktorat Jendral Pajak (DJP) mengeluarkan program baru yang memanfaatkan teknologi dengan lebih baik, yakni e-system yang dimana terdapat beberapa bagian di dalamnya seperti $e$-registration, $e$-filling, e-spt, dan e-billing.

$e$-system merupakan suatu alternatif terbaru yang dikeluarkan oleh Direktorat Jendral Pajak (DJP) di dalam pelayanan pajak. Sistem ini merupakan rangkaian untuk pemrosesan dalam administrasi perpajakan yang dapat diakses melalui internet yang sudah terintegrasi dengan kantor pelayanan pajak. e-billing adalah metode untuk pembayaran pajak secara online maupun melalui atm dengan memasukkan kode billing yang akan diterima wajib pajak, sedangkan $e$-filing adalah suatu cara penyampaian Surat Pemberitahuan (SPT) secara elektronik yang dilakukan secara online dan real time melalui internet pada website direktorat jenderal pajak.

Persepsi kegunaan menjadi penentuapakah diterima atau tidaknya suatu sistem oleh pengguna. Dalam penerapan sistem e-filing dan e-billing, apabila Wajib Pajak beranggapan bahwa sistem efiling dan e-billing bermanfaat bagi mereka dalam pelaporan maupun penyetoran pajaknya maka akan menyebabkan ketertarikan menggunakan sistem tersebut. Kualitas suatu sistem dapat mempengaruhi keberhasilan sistem tersebut dalam memenuhi kebutuhan pengguna dan sangat menentukan kepuasan Wajib Pajak yang menggunakan sistem tersebut. Jika pengguna merasa puas akan kualitas sistem tersebut maka Wajib Pajak akan secara 
terus-menerus menggunakannya untuk memenuhi kewajiban perpajakan mereka, sehingga kepuasan penggunaan suatu sistem oleh pemakai menjadi tolak ukur keberhasilan suatu sistem. Dengan metode baru ini diharapkan dapat memberikan kemudahan bagi wajib pajak untuk mengakses dimanapun dan kapanpun. Dengan adanya pembaharuan sistem pelayanan dan administrasi perpajakan diharapkan dapat mendorong wajib pajak di dalam pemenuhan kewajiban sebagai warga negara yang baik yang mungkin akan meningkatkan kepuasan bagi wajib pajak itu sendiri.

\section{TINJAUAN PUSTAKA}

\section{Technology Acceptance Model (TAM)}

Technology Acceptance Model (TAM) merupakan salah satu teori tentang penggunaan sistem teknologi informasi yang dianggap sangat berpengaruh dan umumnya digunakan untuk menjelaskan penerimaan individual terhadap penggunaan sistem informasi. Teori ini pertama kali dikenalkan oleh davis (1989). Teori ini dikembangkan dari Theory of Reasoned Action (TRA) oleh Ajzen dan Fishbein (1980). Davis menyatakan TAM merupakan model yang digunakan untuk memprediksi penerimaan pengguna terhadap teknologi berdasarkan dua variabel, yaitu persepsi kemanfaatan (perceived usefulness) didefinisikan sebagai tingkat kepercayaan pengguna bahwa dengan menggunakan suatu item, maka akan dapat meningkatkan kinerja pengguna, sedangkan persepsi kemudahan pengguna (perceived easy of use) sebagai tingkat kepercayaan pengguna bahwa sistem dapat digunakan dengan mudah dan dapat dipelajari sendiri.

Technology Acceptance Model (TAM) dapat dideskripsikan menjadi yang secara dominan mempengaruhi integrasi teknologi. Faktor pertama adalah persepsi kegunaan (usefulness), sedangkan faktor kedua adalah persepsi kemudahan dalam penggunaan teknologi (easy of use). TAM dalam penelitian ini digunakan sebagai dasar pengambilan variabel yaitu bahwa penggunaan (usefulness) ebilling dan e-filing dapat memberikan kemudahan sebagai pengguna teknologi informasi (perceived easy of use) yang akan memberikan kepuasan sebagai pengguna.

\section{Task Technology Fit (TTF)}

Task Technology Fit (TTF) dikembangkan oleh Goodhue dan Thompson (1995). TTF adalah tingkat dimana teknologi membantu individu dalam pelaksanaan tugas-tugasnya atau tugas jabatan. Secara lebih spesifik, TTF merupakan penyesuaian antara kebutuhan akan tugas-tugas, kemampuan individu dan fungsi teknologi. Prioritas TTF adalah interaksi antara tugas, teknologi, dan individu. Berbagai macam tugas yang pasti membutuhkan berbagai macam fungsi teknologi yang pasti. Model ini mengindikasikan bahwa kinerja akan meningkat ketika sebuah teknologi menyediakan fitur dan dukungan yang tepat dikaitkan dengan tugas.

Contoh : sistem $e$-billing dan $e$-filing yang memiliki fungsi sebagai sarana pembayaran \& pelaporan pajak dapat membantu wajib pajak dalam membayar serta melaporkan pajak secara online dan realtime.

\section{Kualitas Sistem}

Mengukur kualitas sistem informasi merupakan hal yang tidak mudah, hal ini dikarenakan tidak adanya kriteria yang menjadi standar untuk menentukan kualitas sistem informasi. Pengukuran kualitas sistem dapat dilakukan dengan melihat efektifitas suatu sistem informasi yang dijalankan di dalam perusahaan. Pengukurpengukur kualitas sistem informasi menurut adalah sebagai berikut :

A. Easy of use. Suatu sistem informasi dapat dikatakan berkualitas jika sistem tersebut dirancang untuk memenuhi kepuasan pengguna melalui kemudahan dalam menggunakan sistem informasi tersebut. Davis mengungkapkan kemudahan yang dipersepsikan adalah tingkatan dimana seseorang percaya bahwa penggunaan suatu sistem tertentu dapat menjadikan orang tersebut bebas dari usaha (free of effort). Bebas dari usaha yang dimaksud adalah seseorang menggunakan sistem, ia hanya memerlukan sedikit waktu untuk mempelajari sistem tersebut sederhana, tidak rumit, dan mudah dipahami, sudah dikenal (familiar).

B. Response Time. Kecepatan akses merupakan salah satu indikator kualitas sistem informasi. Jika akses sistem informasi memiliki kecepatan yang optimal maka layak dikatakan bahwa informasi yang diterapkan memiliki kualitas yang baik. Kecepatan akses akan meningkatkan kepuasan pengguna dalam menggunakan sistem informasi.

C. Reliability. Sistem informasi yang berkualitas adalah sistem informasi yang dapat diandalkan. Jika sistem tersebut dapat diandalkan maka sistem informasi tersebut layak digunakan. Keandalan sistem informasi dalam konteks ini juga dapat dilihat dari sistem informasi yang melayani 
kebutuhan pengguna tanpa adanya masalah yang dapat mengganggu kenyamanan pengguna dalam menggunakan sistem informasi.

D. Flexibility. Fleksibilitas suatu sistem informasi menunjukkan bahwa sistem informasi yang diterapkan tersebut memiliki kualitas yang baik. Fleksibilitas yang dimaksud adalah kemampuan sistem informasi dalam melakukan perubahan-perubahan kaitannya dengan memenuhi kebutuhan pengguna. pengguna akan merasa lebih puas menggunakan suatu sistem informasi jika sistem tersebut fleksibel dalam memenuhi kebutuhan pengguna.

E. Security. Suatu sistem informasi dapat dikatakan baik jika keamanan sistem tersebut dapat diandalkan. Keamanan sistem ini dapat dilihat melalui data pengguna yang aman disimpan oleh suatu sistem informasi. Data pengguna ini harus terjaga kerahasiaannya dengan cara data disimpan oleh sistem informasi sehingga pihak lain tidak dapat mengakses data pengguna secara bebas. Jika data pengguna dapat disimpan secara aman maka akan memperkecil kesempatan pihak lain untuk menyalahgunakan data pengguna sistem informasi.

\section{E-Filing}

Berdasarkan Keputusan Direktur Jenderal Pajak Nomor Kep-88/PJ/2004 tentang Penyampaian Surat Pemberitahuan secara Elektronik dalam Pasal 1 "Direktur Jenderal Pajak memutuskan bahwa "Wajib Pajak dapat menyampaikan Surat Pemberitahuan secara elektronik melalui perusahaan Penyedia Jasa Aplikasi (Apllication Service Provider) yang ditunjuk oleh Direktur Jenderal Pajak”.

e-filing adalah suatu cara penyampaian Surat Pemberitahuan (SPT) baik SPT Masa, maupun SPT Tahunan atau Pemberitahuan Perpanjangan SPT Tahunan oleh Orang Pribadi maupun Badan ke Direktorat Jenderal Pajak yang dilakukan secara online dan realtime melalui Penyedia Jasa Aplikasi atau Application Service Provider (ASP).

\section{E-Billing}

E-billing merupakan salah satu bentuk modernisasi administrasi perpajakan untuk mengoptimalkan pelayanan Direktorat Jendral Pajak pada wajib pajak. E-billing adalah serangkaian proses yang meliputi kegiatan pendaftaran peserta billing, pembuatan kode billing, pembayaran berdasarkan kode billing dan rekonsiliasi billing dalam system modul penerimaan negara.

Pembayaran pajak dapat dilakukan dengan menyetor uang ke bank/pos persepsi dengan membawa kode billing. Setelah melakukan pembayaran wajib pajak akan diberikan bukti penerimaan negara.

\section{Kepuasan Pengguna (Wajib Pajak)}

Kepuasan pengguna dapat tercipta melalui efektivitas sebab adanya sistem organisasi yang sukses dalam pemenuhan kebutuhan pelanggan. Kepuasan pelanggan dapat dicapai bila terjadi pemenuhan kebutuhan atau keinginan pengguna (Rahmat, 2009:26). Kepuasan pelanggan mengacu kepada dua variabel, yakni pelayanan yang diharapkan dan pelayanan yang dirasakan oleh pengguna (Kotler, 2002:42).

Kepuasan wajib pajak merupakan gambaran dari keselarasan, antara harapan, keinginan, kebutuhan seseorang dengan hasil yang didapatkan lantaran adanya sebuah sistem.Tanpa ditunjang dengan sistem organisasi yang baik maka pelayanan yang memuaskan tidak dapat terjadi. Kepuasan pengguna sistem menunjuk kepada suatu keadaan dimana pengguna merasa puas setelah menggunakan sistem tersebut karena kemudahan yang dimiliki oleh sistem. Dengan kata lain, semakin pengguna menyukai suatu sistem, secara implisit mereka puas dengan sistem yang dimaksud. Kepuasan pengguna adalah keseluruhan evaluasi dari pengalaman pengguna dalam menggunakan sistem informasi dan dampak potensil dari sistem informasi. Hal ini diwujudkan dengan kecendrungan peningkatan pengguna sistem informasi tersebut. Sebaliknya, jika sistem informasi tidak memenuhi kebutuhan pengguna maka kepuasan pengguna tidak akan meningkat dan penggunaan lebih lanjut akan dihindari.

Kepuasan pengguna ini berhubungan dengan kesuksesan sistem informasi dan kualitas informasi yang dihasilkan oleh sistem. Keduanya diasumsikan dapat mempengaruhi kepuasan pengguna sistem informasi. Semakin baik kualitas sistem dan kualitas informasi yang dihasilkan maka kepuasan atas sistem informasi tersebut juga akan semakin meningkat. Sistem informasi dapat diandalkan apabila memiliki kualitas sistem dan kualitas informasi yang baik dan mampu memberikan kepuasan pada pemakainya. Jika pengguna sistem informasi percaya bahwa kualitas sistem dan kualitas informasi yang dihasilkan dari sistem yang digunakan adalah baik, mereka akan puas menggunakan sistem tersebut. Kepuasan pengguna sistem ini juga berpengaruh terhadap individual impact. Jika pengguna sering memakai sistem informasi maka semakin banyak tingkat 
pembelajaran (degree of learning) yang didapat dari sistem informasi, peningkatan derajat pembelajaran ini merupakan salah satu indikator bahwa sistem informasi telah memberikan pengguna lebih memahami konteks keputusan, telah memperbaiki keputusan produktivitas, telah menghasilkan perunahan dalam aktifitas pengguna, dan telah mengubah keputusan persepsi mengenai pentingnya atau kegunaan dari sistem informasi. Keberadaan sistem informasi baru akan menjadi stimulus bagi individu dalam organisasi untuk bekerja dengan baik.

\section{Kerangka Pemikiran}

Kerangka pemikiran dalam penelitian ini disusun seperti dalam bagan berikut ini:

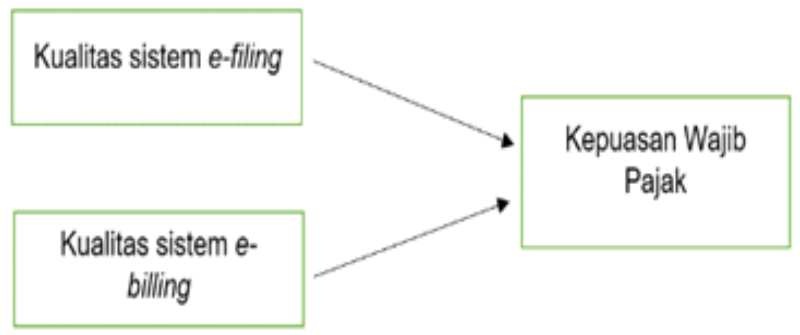

Gambar 1 Kerangka Pemikiran

Pada penelitian ini akan dilakukan analisis pengaruh kualitas sistem media elektronik $e$-filing dan $e$-billing terhadap tingkat kepuasan wajib pajak.

\section{Hipotesis} berikut:

Hipotesis pada penelitian ini adalah sebagai

$\mathrm{H}_{1}$ : Kualitas sistem media elektronik $e$ filing berpengaruh terhadap tingkat kepuasan wajib pajak

$\mathrm{H}_{2}$ : Kualitas sistem media elektronik ebilling berpengaruh terhadap tingkat kepuasan wajib pajak

$\mathrm{H}_{3}$ : Kualitas sistem media elektronik $e$ filing dan e-billing secara bersamasama berpengaruh terhadap tingkat kepuasan wajib pajak

\section{METODE}

\section{Populasi dan Sample}

Populasi dalam penelitian ini adalah Wajib Pajak Khususnya dosen tetap dan mahasiswa Fakultas Ekonomi di Universitas Tridinanti Palembang yang menggunakan media elektronik e-filing dan e-billing.

Teknik pemilihan sampel yang digunakan dalam penelitian ini adalah metode purposive sampling, dengan tujuan untuk mendapatkan sampel yang representative sesuai dengan kriteria yang ditentukan.

\section{Definisi Oprasional Variabel}

Operasional variabel untuk melakukan penelitian ini tertuang dalam tabel di bawah ini:

Tabel 1

Operasional Variabel

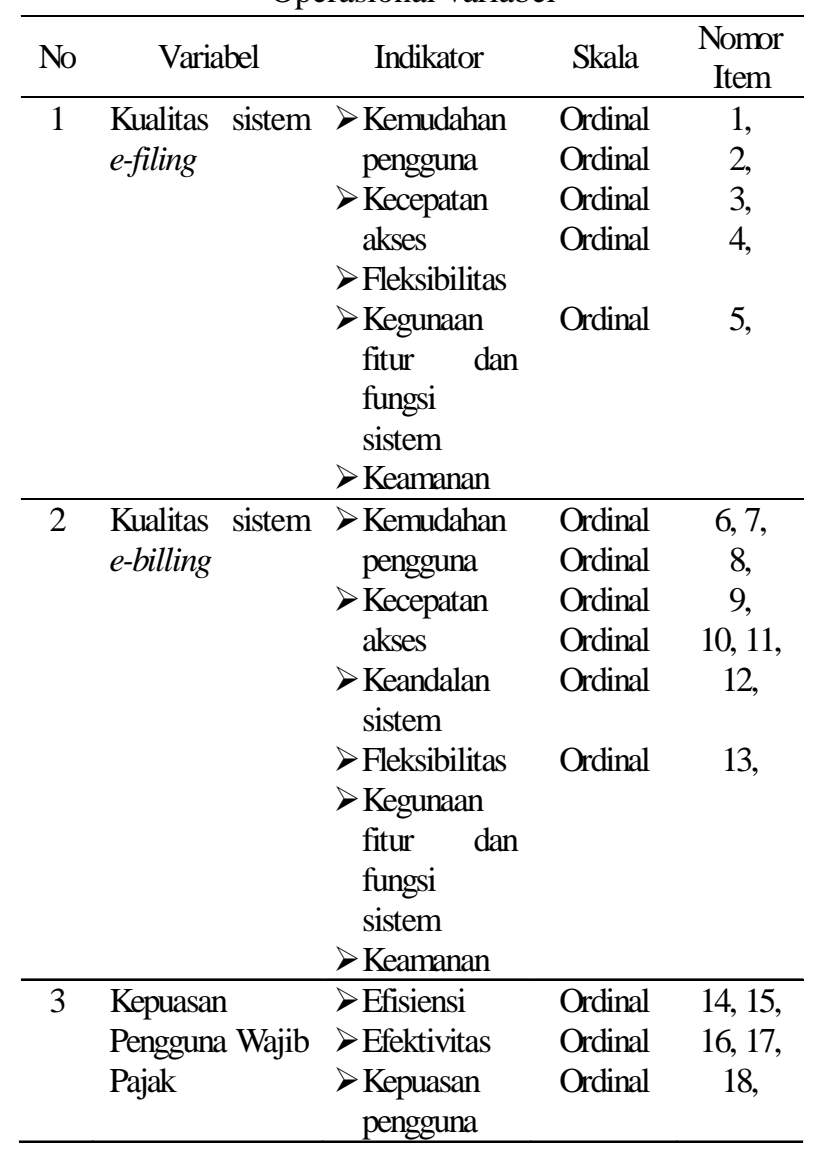

\section{Teknik Pengumpulan Data}

Teknik pengumpulan data di dalam penelitian ini menggunakan kuesioner, yakni mengumpulkan data dengan mengajukan sejumlah pertanyaan kepada responden dalam bentuk daftar pertanyaan dan diminta untuk memberikan tanggapan atau jawaban yang telah tersedia pada metode ini digunakan skala pengukuran model likert scale (skala Likert) dengan rentang skala 1 sampai dengan 5 seperti berikut:

Tabel 2

Skala Likert

\begin{tabular}{cclc}
\hline No & Notasi & \multicolumn{1}{c}{ Keterangan } & Nilai \\
\hline 1 & STS & Sangat Tidak Setuju & 1 \\
\hline 2 & TS & Tidak Setuju & 2 \\
\hline 3 & RR & Ragu-Ragu & 3 \\
\hline 4 & S & Setuju & 4 \\
\hline 5 & SS & Sangat Setuju & 5
\end{tabular}




\section{Metode Analisis Data}

1) Analisis Deskriptif. Uji statistik deskriptif dalam penelitian ini digunakan untuk mendeskripsikan data yang ada di dalam penelitian ini yang terdiri dari kualitas sistem media elektronik e-filing dan e-billing dengan tingkat kepuasan wajib pajak; 2) Uji Instrument. Titik tolak penyusunan instrumen penelitian adalah variabel-variabel penelitian yang ditetapkan untuk diteliti, dari variabel-variabel tersebut diberikan definisi operasionalnya, dan selanjutnya ditentukan indikator yang akan diukur, kemudian dari indikator tersebut dijabarkan menjadi butir pertanyaan atau pernyataan. Maka penelitian menggunakan intrumen sebagai berikut: a) Instrumen Validasi, instrumen yang valid merupakan alat ukur yang dapat digunakan untuk mendapatkan data yang valid, yaitu dapat digunakan untuk mengukur apa yang seharusnya diukur (Sugiyono, 2009:121), b) Instrument Reliabilitas, reliabilitas menunjukkan sejauh mana hasil pengukuran dengan alat tersebut dapat dipercaya. Hasil pengukuran harus reliabel dalam artian harus memiliki tingkat konsistensi dan kemantapan. Uji reliabilitas dilakukan dengan menggunakan metode Alpha Cronbach's dan diukur berdasarkan skala Alpha Cronbac's 0 sampai 1. Reliabilitas suatu konstruk variabel dikatakan baik jika memiliki nilai Alpha Cronbach's > 0,60 (Uma, 2008:53); 3) Uji Asumsi Klasik, a) Uji Normalitas Bertujuan untuk menguji apakah dalam model regresi, variabel pengganggu atau residual memiliki distribusi normal. Terdapat dua cara untuk mendeteksi apakah residual berdistribusi normal atau tidak yaitu dengan analisi grafik dan uji statistik. Dengan melihat normal probability plot yang membandingkan distribusi kumulatif dari distribusi normal. Sedangkan uji statistik sederhana dapat dilakukan dengan uji statistik non-parametrik Kolmogorov-Smirnov (Ghozali,2009), b) Uji Heteroskedestisitas, uji heteroskedestisitas bertujuan untuk menguji apakah regresi terjadi ketidaksamaan varians dari residual satu pengamatan ke pengamatan yang lain, c) Uji Multikolinieritas, uji multikolinearitas bertujuan untuk menguji apakah dalam model regresi ditemukan adanya korelasi antar variabel bebas (independen). Model regresi yang baik seharusnya tidak terjadi korelasi diantara variabel bebas.

\section{Hipotesis}

1) Uji Simultan (Uji f), hasil uji kelayakan model (Uji Statistik F) menunjukkan apakah semua variabel independen yang dimasukkan dalam model mempunyai pengaruh secara bersama-sama terhadap variabel dependen. ANOVA (Analisis of Variance) dapat digunakan untuk melakukan uji signifikansi $\mathrm{F}$ dengan á $=0,05$. Apabila hasil perhitungan menunjukkan: a) Jika nilai signifikan $<0,05$ maka variabel independent secara bersama-sama berpengaruh signifikan positif terhadap variabel dependen. b) Jika nilai signifikan $>0,05$ maka variabel independent secara bersama-sama berpengaruh signifikan positif terhadap variabel dependen; 2) Uji Parsial (Uji t), Uji Parsial (Uji t) digunakan untuk mengetahui apakah variabel independen yang terdapat dalam persamaan regresi secara individual berpengaruh terhadap nilai variabel dependen, dengan á $=5 \%$. Apabila hasil menunjukkan: a) Jika probabilitas (signifikansi) $\mathrm{t}<$ á $=0,05$ maka Ho ditolak dan Ha diterima artinya variabel bebas dapat menerangkan variabel tidak bebas dan ada pengaruh diantara dua variabel yang diuji. b) Jika probabilitas (signifikansi) t $>$ á $=0,05$ maka Ho diterima dan Ha ditolak artinya variabel bebas tidak dapat menerangkan variabel tidak bebas dan tidak ada pengaruh diantara dua variabel yang di uji.

\section{HASIL DAN PEMBAHASAN}

\section{Deskripsi Responden}

Jumlah kuesioner yang disebar sebanyak 150 kuesioner, kuesioner yang kembali dan dapat diolah hanya sebanyak 130 kuesioner. Setelah masa pengedaran kuesioner berakhir, peneliti melakukan editing, coding dan data entry untuk persiapan analisis data. Hasilnya ternyata tidak semua kuesioner dapat dijadikan sebagai dasar analisis. Berikut perhitungan analisis data kuesioner:

a. Jumlah kuesioner beredar 150 eks

b. Kuesioner tidak kembali 15 eks

c. Kuesioner cacat data 5 eks

Jumlah kuesioner yang dapat diolah $\quad \overline{130 \mathrm{eks}}$

Dengan demikian respon rate pengembalian kuesioner adalah sebesar 86,67\% (130/150). Subjek dalam penelitian ini adalah Dosen tetap dan Mahasiswa Fakultas Ekonomi Universitas Tridinanti Palembang. Data mengenai karakteristik responden ditampilkan pada table berikut:

a. Deskripsi Responden Berdasarkan Jenis Kelamin

Hasil uji deskripsi responden berdasarkan jenis kelamin adalah sebagai berikut:

Tabel 3

\begin{tabular}{|c|c|c|}
\hline \multicolumn{3}{|c|}{ Jenis Kelamin Responden } \\
\hline Jenis Kelamin & Jumlah & Persentase \\
\hline Pria & 80 & $61,54 \%$ \\
\hline Wanita & 50 & $38,46 \%$ \\
\hline Total & 130 & $100 \%$ \\
\hline
\end{tabular}


Dari tabel 3 dapat dilihat bahwa jumlah responden pria sebesar 80 atau $(61,54 \%)$ dan jumlah responden wanita sebesar 50 atau $(38,46 \%)$ terlihat bahwa responden pria mendominasi dibandingkan wanita.

b. Deskripsi responden berdasarkan Pekerjaan

Hasil uji deskripsi responden dengan berdasarkan Pekerjaan adalah sebagai berikut:

Tabel 4

Pekerjaan Responden

\begin{tabular}{ccc}
\hline Pekerjaan & Jumlah & Persentase \\
\hline P N S & 10 & $7,70 \%$ \\
\hline SW AST A & 100 & $76,92 \%$ \\
\hline LAIN-LAINNY A & 20 & $15,38 \%$ \\
\hline Total & $\mathbf{1 3 0}$ & $\mathbf{1 0 0} \%$ \\
\hline
\end{tabular}

Dari table 4 dapat dilihat bahwa 10 orang responden (7,70\%) adalah PNS, 100 orang adalah pekerja Swasta (76,92\%), dan lain-lainnya sebesar 20 orang (15,38\%). Dapat di lihat bahwa responden yang bekerja di perusahaan swasta mendominasi jumlah responden pada penelitian ini.

\section{Hasil Uji Instrumen Penelitian}

Uji Instrumen Validitas, untuk melihat validitas setiap item kuesioner dengan cara membandingkan antara $\mathrm{r}_{\text {tabel }}$ dan $\mathrm{r}_{\text {hitung, jika } \mathrm{r}_{\text {hitung }}>\mathrm{r}_{\text {tabel }} \text { maka }}$ seluruh item pernyataan pada kuesioner adalah valid dan dapat digunakan ketahap selanjutnya. Berdasarkan hasil pengelolaan data dengan spss yang menggunakan sample 30 responden, maka diperoleh data rhitung sebagai berikut:

Tabel 5

Hasil Uji Validitas

\begin{tabular}{|c|c|c|c|c|}
\hline Variabel & $\begin{array}{c}\text { Butir } \\
\text { Instrumen }\end{array}$ & $\begin{array}{c}\mathrm{r}- \\
\text { hitung }\end{array}$ & $\begin{array}{c}\mathrm{r}- \\
\text { tabel }\end{array}$ & $\begin{array}{c}\text { Hasil } \\
\text { Uji }\end{array}$ \\
\hline \multirow[t]{5}{*}{$\begin{array}{c}\text { Kualitas S istem } \\
e \text {-filing }\end{array}$} & $\mathrm{X} 1.1$ & 0,632 & 0,349 & V alid \\
\hline & $\mathrm{X} 1.2$ & 0,543 & 0,349 & Valid \\
\hline & X 1.3 & 0,669 & 0,349 & Valid \\
\hline & $\mathrm{X} 1.4$ & 0,683 & 0,349 & Valid \\
\hline & X1.5 & 0,742 & 0,349 & V alid \\
\hline \multirow{8}{*}{$\begin{array}{c}\text { Kualitas S istem } \\
e \text {-billing }\end{array}$} & $\mathrm{X} 2.1$ & 0,517 & 0,349 & Valid \\
\hline & $\mathrm{X} 2.2$ & 0,476 & 0,349 & Valid \\
\hline & X2.3 & 0,587 & 0,349 & V alid \\
\hline & X2.4 & 0,505 & 0,349 & Valid \\
\hline & X2.5 & 0,541 & 0,349 & Valid \\
\hline & X2.6 & 0,607 & 0,349 & V alid \\
\hline & X2.7 & 0,615 & 0,349 & Valid \\
\hline & $\mathrm{X} 2.8$ & 0,558 & 0,349 & Valid \\
\hline \multirow[t]{5}{*}{$\begin{array}{c}\text { Kepuasan } \\
\text { Pengguna } \\
\text { Wajib Pajak } \\
\end{array}$} & $\mathrm{Y} 1$ & 0,684 & 0,349 & Valid \\
\hline & Y 2 & 0,701 & 0,349 & Valid \\
\hline & Y3 & 0,647 & 0,349 & Valid \\
\hline & Y 4 & 0,486 & 0,349 & Valid \\
\hline & Y5 & 0,640 & 0,349 & Valid \\
\hline
\end{tabular}

One-Sample Kolmogorov-Smirnov Test
Adapun hasil pengujian dapat dilihat bahwa rhitung $>\mathrm{r}_{\text {tabel }}$ sehingga semua item pernyataan pada kuesioner adalah valid.

\section{Uji Instrumen Reliabilitas}

Uji reliabilitas untuk menunjukkan sejauh mana suatu alat pengukuran dapat dipercaya atau dapat diandalkan. Oleh karena itu hasil pengujian reliabilitas sebagai berikut:

\section{Tabel 6}

Uji Reliabilitas

\begin{tabular}{lccc}
\hline \multicolumn{1}{c}{ Variabel } & $\begin{array}{c}\text { Cronbach’s } \\
\text { Alpha }\end{array}$ & $\begin{array}{c}\text { Batas } \\
\text { Reliabilitas }\end{array}$ & Keterangan \\
\hline $\begin{array}{l}\text { Kepuasan } \\
\text { Pengguna }\end{array}$ & 0,614 & 0,6 & Reliabel \\
$\begin{array}{l}\text { Wajib Pajak } \\
(\mathrm{Y})\end{array}$ & & 0,6 & Reliabel \\
\hline $\begin{array}{l}\text { Kualitas } \\
\text { sistem } \\
e \text {-filing }\left(\mathrm{X}_{1}\right)\end{array}$ & 0,620 & & \\
\hline $\begin{array}{l}\text { Kualitas } \\
\text { sistem } \\
e-\text {-billing }\end{array}$ & 0,661 & 0,6 & Reliabel \\
$\left(\mathrm{X}_{2}\right)$ & & & \\
\hline
\end{tabular}

Berdasarkan hasil olahan data dapat dilihat bahwahasil perhitungan uji reliabilitas menunjukkan Cronbach's Alpha lebih besar dari batas reliabilitas 0,6 , maka dapat dinyatakan bahwa instrument dalam penelitian tersebut dapat dikatakan reliabel atau andal.

\section{Uji Asumsi Klasik}

Uji Normalitas Data

Tabel 7

Hasil Uji Normalitas

One-Sample Kolmogorov-Smirnov Test

\begin{tabular}{llc}
\hline & & $\begin{array}{c}\text { Unstandardiz } \\
\text { ed Residual }\end{array}$ \\
\hline \multirow{3}{*}{ Normal Parameters } & $\mathrm{N}$ & 130 \\
& Mean & 00000000 \\
Most Extreme Diflerences & Std. Deviation & .95716770 \\
& Absolute & .079 \\
& Positive & .057 \\
& Negative & .079 \\
& Kolmogorov & \\
& Smirnov Z & .905 \\
& Asymp. Slg (2 talled) .386 \\
\hline
\end{tabular}

a. Test distribution is Normal

b. Calculated fram data

Untuk melihat normalitas data penelitian ini menggunakan pengujian Kolmogorov Smirnov. Hasil olahan data menunjukkan bahwa data berdistribusi normal karena nilai signifikansinya 0,386 lebih besar dari 0,05 dengan nilai Kolmogorov 
Smirnov sebesar 0,905. Data yang baik dan dikatakan normal jika memiliki tingkat signifikan yang lebih besar dari 0,05.

\section{Uji Multikolinearitas}

Uji multikolinearitas bertujuan untuk menguji apakah model regresi ditemukan adanya korelasi antar variable bebas. Model regresi yang baik seharusnya tidak terjadi korelasi antara variable independen. Hasil pengujian multikolinearitas sebagai berikut:

Tabel 8

Hasil Uji Multikolinearitas

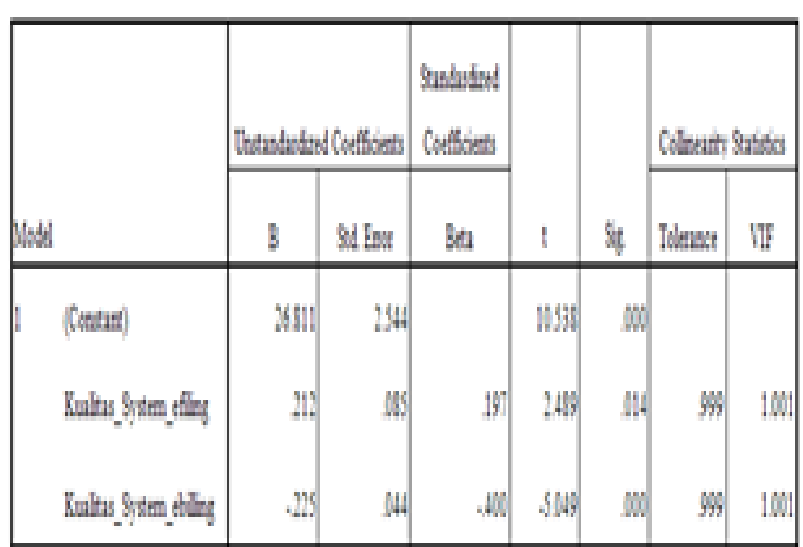

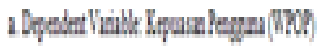

Dasar pengambilan keputusan pada uji multikolinearitas adalah: 1) Nilai tolerance: a. Jika nilai tolerance $>0,10$ artinya tidak terjadi multikolinearitas terhadap data yang diuji; b. Jika nilai tolerance $<0,10$ artinya terjadi multikolinearitas terhadap data yang diuji; 2) Nilai VIF: a. Jika nilai VIF $<10,00$ artinya tidak terjadi multikolinearitas terhadap data yang diuji; b. Jika nilai VIF $>10,00$ artinya terjadi multikolinearitas terhadap data yang diuji.

Dari hasil pengujian dapat dilihat variable $\left(\mathrm{X}_{1}\right)$ dan variable $\left(\mathrm{X}_{2}\right)$ tolerancenya 0,999 lebih besar dari 0,10 artinya tidak terjadi multikolinearitas terhadap data yang diuji. Selanjutnya seluruh variabel nilai VIF 1,001 lebih kecil dari 10,00 sehingga dapat disimpulkan seluruh variable tidak terjadi multikolinearitas.

\section{Uji Heterokedastisitas}

Tabel 9

Uji Glejser

coefficient'

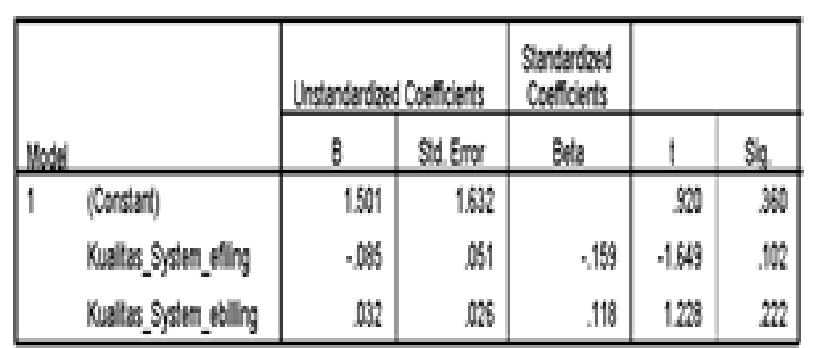

a Dependert Variste: RES?

Untuk membuktikan tidak terjadi heterokedastisitas dapat diketahui dengan melihat bahwa nilai sig $>0,05$ tidak terjadi heterokedastisitas dan sebaliknya $<0,05$ terjadi heterokedastisitas. Pada gambar diatas dapat dilihat bahwa seluruh variable mendapatkan nilai signifikansinya $>0,05$. Berdasarkan hal ini menunjukkan bahwa tidak terjadi heterokedastisitas pada data penelitian ini.

\section{Koefisien Determinasi (R2)}

\section{Tabel 10}

Uji Koefisiensi Determinasi $\left(\mathrm{R}^{2}\right)$

\begin{tabular}{lcrrr}
\multicolumn{6}{c}{ Model Summary } \\
\hline Model & $\mathrm{R}$ & $\begin{array}{c}\mathrm{R} \\
\text { Square }\end{array}$ & $\begin{array}{c}\text { Adjusted R } \\
\text { Square }\end{array}$ & $\begin{array}{l}\text { Std. Error of } \\
\text { the Estimate }\end{array}$ \\
\hline 1 & $.451^{\mathrm{a}}$ & .204 & .191 & .96468
\end{tabular}

a. Predictors: (Constant), Kualitas_System_ebilling, Kualitas_System_efiling

Berdasarkan hasil olahan data diatas maka diketahui bahwa nilai $\mathrm{R}^{2}$ adalah 0,204 sehingga dapat disimpulkan bahwa variable independen memiliki kontribusi dalam menjelaskan variable dependen sebesar $20,40 \%$.

\section{Uji Hipotesis}

Uji Simultan (Uji F)

Tabel 11

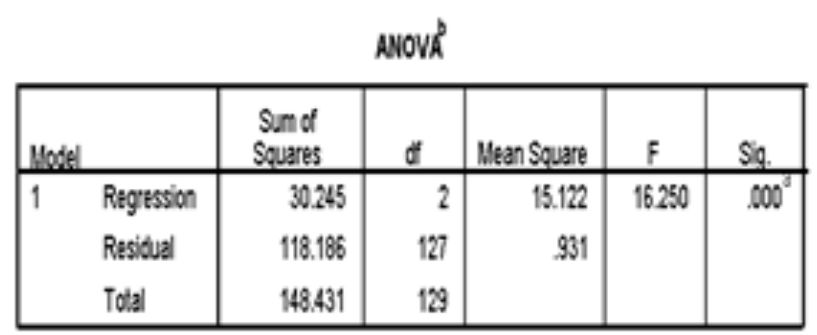

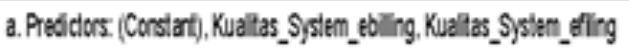

b. Dependert Variable: Keppasen Penoggna (MPCP) 
Dari hasil diatas bahwa $\mathrm{F}$ hitung $16.250>\mathrm{F}$ table 3,07 dengan nilai signifikannya $0,000<0,05$ dengan demikian secara simultan variabel independen berpengaruh positif terhadap variabel dependen.

\section{Uji Parsial (Uji t)}

Tabel 12

Ujit

coumcients

\begin{tabular}{|c|c|c|c|c|c|c|}
\hline \multirow[b]{2}{*}{ Mone } & & \multicolumn{2}{|c|}{ Unstandreread Conficints } & \multirow{2}{*}{ 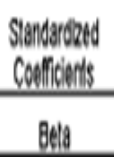 } & \multirow[b]{2}{*}{1} & \multirow[b]{2}{*}{ Sal } \\
\hline & & $B$ & SIO Enory & & & \\
\hline \multirow[t]{3}{*}{1} & (Consiont) & 26811 & 2344 & & 10,398 & .000 \\
\hline & Kualias__system_ffiling & .212 & .085 & 199 & 2689 & .014 \\
\hline & Kusiass system atiling & .225 & .044 & .400 & 5.049 & .000 \\
\hline
\end{tabular}

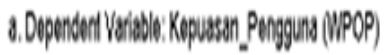

Nilai t table adalah 1,97882 sementara nilai t hitung untuk variable e-filing $\left(\mathrm{X}^{1}\right)$ 2,489, untuk variable e-billing $\left(\mathrm{X}^{2}\right)$-5,049. dengan tingakat signifikannya di bawah 0,05. Kesimpulannya variable e-filing berpengaruh signifikan positif sedangkan e-billing berpengaruh signifikan negative. Dari nilai-nilai koefisiensi diatas dapat di susun persamaan regresi sebagai berikut:

$$
\mathrm{Y}=26.811+2.489+-5.049+\mathrm{e}
$$

\section{Hasil Uji Hipotesis}

Selanjutnya seluruh hasil pengujian hipotesis secara konseptual diringkas sebagai berikut :

Tabel 13

Hasil Pengujian Hipotesis

\begin{tabular}{|c|c|c|}
\hline Hipotesis & Keterangan & Kesimpulan \\
\hline $\mathrm{HI}$ & $\begin{array}{lr}\text { Kualitas sistem media e- } \\
\text { filing } \\
\text { signifikan positif terhadap } \\
\text { tingkat } \\
\text { pengguna wajib pajak }\end{array}$ & $\begin{array}{l}\text { Signifikan } \\
\text { Positif }\end{array}$ \\
\hline $\mathrm{H} 2$ & $\begin{array}{l}\text { Kualitas system media e- } \\
\text { billing berpengaruh } \\
\text { signifikan negative } \\
\text { terhadap tingkat kepuasan } \\
\text { pengguna wajib pajak }\end{array}$ & $\begin{array}{c}\text { Signifikan } \\
\text { Negative }\end{array}$ \\
\hline H3 & $\begin{array}{l}\text { Kualitas sistem media } \\
\text { elektronik e-filing dan e- } \\
\text { billing secara bersama- } \\
\text { sama berpengaruh } \\
\text { signifikan positif terhadap } \\
\text { tingkat kepuasan wajib } \\
\text { pajak }\end{array}$ & $\begin{array}{l}\text { Signifikan } \\
\text { Positif }\end{array}$ \\
\hline
\end{tabular}

\section{HASIL DAN PEMBAHASAN}

Pengaruh system media $e$-filing berpengaruh signifikan positif terhadap tingkat kepuasan pengguna wajib pajak dilihat dari signifikannya di bawah 0,05 dengan t hitungnya lebih besar dari t table. Oleh karena itu dapat di asumsikan bahwa dengan adanya system media $e$-filing yang memiliki kualitas yang baik dan dapat diakses secara rela time dimanapun dan kapanpun akan mempermudah wajib pajak di dalam pelaporan perpajakannya dengan demikian akan memberikan pengaruh positif ke wajib pajak untuk melaksanakan kewajibannya sebagai wajib pajak.

Pengaruh system media e-billing berpengaruh signifikan negative terhadap tingkat kepuasan pengguna wajib pajak dilihat dari signifikannya di bawah 0,05 dengan $t$ hitungnya lebih kecil dari t table. Oleh karena itu dapat di asumsikan bahwa dengan adanya system media $e$-billing akan memberikan kemudahan, lebih cepat, dan akurat, namun di satu sisi pada saat peneliti survey ke lapangan kebanyakan wajib pajak kurang memahami proses pembayaran dengan menggunakan system e-billing apalagi untuk menyetorkan terhutang pajaknya. Oleh karena itu, wajib pajak meminta bantuan ke temannya atau yang paham untuk melakukkan proses pembayaran dengan menggunakan system $e$-billing, belum lagi proses pembayaran lewat ATM sering terjadi listrik dan signal down sehingga mengakibatkan terjadinya eror dan ada beberapa yang dirugikan misalnya pembayaran terjadi dua kali dikarenakan bukti setor tidak keluar dsb. Berkaitan dengan teori DeLone and McLean; 2003 menyatakan bahwa kualitas sistem salah satunya diistilahkan dengan keandalan, ease of use, dan flexibility, dan fungtionality. Jadi terkait temuan diatas bahwa system e-biling masih dirasa kurang reliabel karna masih terjadinya system eror dsb.

Pengaruh system media elektronik e-filing dan e-billing secara bersama-sama berpengaruh signifikan positif terhadap tingkat kepuasan pengguna wajib pajak dilihat dari tingkat signifikansinya di bawah 0,05 dengan $\mathrm{f}$ hitungnya diatas $\mathrm{f}$ table. Oleh karena itu, memang system $e$-filing dan $e$-billing dapat memberikan manfaat yang baik bagi pengguna apabila wajib pajak tersebut mengikuti dan memahami di dalam menggunakan media elektronik tersebut, sebaliknya apabila tidak maka system media elektronik tersebut tidak bermanfaat dengan maksimal bagi wajib pajak khususnya di lingkungan Universitas Tridinanti Palembang. 


\section{KESIMPULAN DAN SARAN}

\section{Kesimpulan}

Penelitian ini bertujuan untuk menganalisis pengaruh kualitas system media elektronik $e$-filing dan $e$-billing terhadap tingkat kepuasan pengguna wajib pajak. Responden pada penelitian ini berjumlah 130 orang di lingkungan Fakultas Ekonomi Universitas Tridinanti Palembang. Berdasarkan data yang dikumpulkan dan pengujian yang telah dilakukan, maka dapat diambil kesimpulan sebagai berikut : 1) Kualitas sistem media $e$-filing berpengaruh signifikan positif terhadap tingkat kepuasan pengguna wajib pajak; 2) Kualitas system media $e$-billing berpengaruh signifikan negative terhadap tingkat kepuasan pengguna wajib pajak.

\section{Saran}

Penelitian ini dimasa mendatang diharapkan dapat menyajikan hasil yang lebih berkualitas lagi dengan adanya beberapa masukan mengenai beberapa hal diantaranya: 1) Peneliti selanjutnya diharapkan menambah variable lainnya yang berhubungan dengan pengguna sistem media elektronik $e$-filing dan $e$-billing; 2) Penelitian selanjutnya agar menambah jumlah sampel dan menambah jumlah variable yang sekiranya dapat lebih menjelaskan juga menggambarkan secara lebih detail mengenai pandangan para Wajib Pajak terhadap system $e$-filing dan $e$-billing; 3)Pihak Direktorat Jendral Pajak (DJP) hendaknya lebih mensosialisasikan lagi bagaimana di dalam mengimplementasikan media elektronik $e$-filing dan $e$-billing secara umum di ruang lingkup pendidikan dan secara khusus di lingkungan Universitas Tridinanti Palembang.

\section{DAFTAR PUSTAKA}

Ajzen, I., Fishbein, M. 1980. Understanding attitudes and Predicting Social Behavior. NJ: Prentice Hall. New Jersey.

DeLone, W., and McLean E.R. 2003. The DeLone and McLean Model of Information System Success: A Ten Year Update. Journal of Management Information Systems. Akses 28 Februari 2018.

Ghozali, Imam. 2009. Aplikasi Analisis Multivariate Dengan Program SPSS. Cetakan Keempat. Badan Penerbit Universitas Diponegoro: Semarang.

Goodhue, D.L.,Thompson R.L.1995. Task Technology Fit and Individual Performance. MIS Quarterly, Vol. 19, No.2,pp 213-236. University of Minessota. Akses 15 November 2017.
Husnurrosyidah, dan Suhadi. 2017. Pengaruh e-filling, e-billing, dan e-faktur Terhadap Kepatuhan Pajak Pada BMT Se-Kabupaten Kudus. Jurnal Analisa Akuntansi dan Perpajakan. Vol 1, No. 1, PP. 97-106. Akses 5 Desember 2017.

Kotler, Philip. 2002. Manajemen Pemasaran : Analisis, Perencanaan, Implementasi dan Kontrol, terj : Hendra Teguh dan Ronny Antonius Rusly. Edisi 9, Jilid 1 dan 2, Jakarta: PT Prenhalindo.

Novita, M. H, dan Noviari, N. 2016. Pengaruh Persepsi Manajemen Atas Keunggulan Penerapan e-billing dan e-spt Pajak Pertambahan Nilai Pada Kepatuhan Perpajakan. E-Jurnal Akuntansi Universitas Udayana. Vol. 15, No. 2 PP 1001-1028. Akses 5 Desember 2017.

Peraturan Direktur Jenderal Pajak Nomor 26 Tahun 2014. Tentang Sistem Pembayaran Pajak Secara Elektronik.

Peraturan Direktur Jenderal Pajak Nomor 88 Tahun 2004. Tentang Tentang penyampaian SPT Secara Elektronik.

Republik Indonesia. Undang-undang No. 28 Tahun 2007. Tentang Ketentuan Umum dan Tata Cara Perpajakan.

Republik Indonesia. Undang-undang No 36 Tahun 2008. Tentang Pajak Penghasilan.

Resmi, Siti. 2011. Perpajakan:Teori dan Kasus. Edisi ke6. Salemba empat: Jakarta.

Sugiyono. 2009. Metode Penelitian Kuantitatif, Kualitatif, dan R\&D. Penerbit Alfabeta: Bandung.

Uma Sekaran, 2006. Metodologi Penelitian untuk Bisnis, Edisi 4. Salemba Empat: Jakarta. 